\title{
Heeft zelfregulering nog toekomst?
}

\section{Roger Dassen}

Op de dag van het schrijven van deze regels, om precies te zijn 1 maart 2005, wordt in Parijs de Public Interest Oversight Board (PIOB) opgericht, die als doel heeft om toezicht te houden op de standards setting activiteiten van de International Federation of Accountants (IFAC). Een lang verwachte ge-

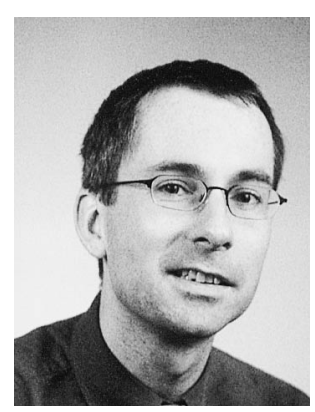
beurtenis, die essentieel is in het model van beperkte zelfregulering dat in een groot aantal landen kenmerkend is voor het accountantsberoep. Laten wij die gebeurtenis even in historisch perspectief plaatsen. Ze leken het zo aardig voor elkaar te hebben, die accountants. Nog geen vijf jaar geleden was er sprake van welhaast volmaakte zelfregulering, in nagenoeg de gehele wereld. Accountants stelden hun eigen regels op, zorgden zelf voor handhaving, bepaalden zelf binnen ruime grenzen aan welke normen nieuwe toetreders moesten voldoen. Niet zo vreselijk anders dan veel andere vrije beroepen, maar wel, zoals in Nederland, met de zegening van een wettelijke taak die was voorbehouden aan leden van de beroepsgroep. En niet zonder succes, want ondanks discussies over verwachtingskloven en incidentele kritiek op de ivoren torenbenadering van accountants, stond er wel een beroep dat in honderd jaar een indrukwekkende statuur had weten te realiseren. De afgelopen tien jaar ging het evenwel mis. Ook al vóór het Enron-schandaal, dat voor veel accountants als de trendbreuk bij uitstek te boek staat. Want al in de jaren negentig waren er vanuit de kant van vooral de toezichthouders aardig wat

Prof. Dr. R. Dassen RA is partner van Deloitte Accountants en tevens hoogleraar Auditing aan de Vrije Universiteit. Hij studeerde economie en accountancy aan de Universiteit Maastricht, waar hij in 1995 promoveerde. verwijten aan het adres van het accountantsberoep. Daarbij kunnen wij denken aan bijvoorbeeld de bancaire crisis in Azië, als gevolg waarvan de Wereldbank de internationale accountantsorganisaties flink op de korrel nam over hun kennelijke onvermogen om met hun 'quality control' te voorkomen dat er goedkeurende verklaringen prijkten onder jaarrekeningen waarin kredietportefeuilles te optimistisch waren gewaardeerd. Of denk aan de legendarische 'Numbers Game'toespraak van de toenmalige SEC-voorzitter Arthur Levitt aan het einde van de jaren negentig, waarin hij zijn ongenoegen uitsprak over het grote aantal gedwongen 'restatements' in jaarrekeningen van in de Verenigde Staten beursgenoteerde bedrijven, en waarin hij openlijk de vraag stelde waarom ook accountants er niet in waren geslaagd om de achteraf gebleken fouten in een eerder stadium geredresseerd te krijgen. De vrees die Levitt uitsprak, en die mede werd gevoed door het extreme variabele beloningensysteem voor topmanagement in (onder meer) de Verenigde Staten, werd enige jaren na zijn toespraak op afschrikwekkende wijze bewaarheid, door de bekende reeks boekhoudschandalen. En waar Levitt's zorgen in eerste instantie werden weggewuifd, zowel door het accountantsberoep als door de politiek, ontstond na deze gebeurtenissen een breed gedragen, luide roep om hervormingen in het financiële systeem, waaronder de accountantscontrole.

De reactie op deze luide roep is voor wat betreft de organisatie van het accountantsberoep niet uniform geweest. Zo is in de Verenigde Staten het systeem van zelfregulering van accountants nagenoeg geheel ten grave gedragen, in elk geval voor wat betreft de beursgenoteerde ondernemingen, die zoals bekend aldaar het leeuwendeel van de accountantscontrolemarkt uitmaken. Met de oprichting van de Public Company Accounting Oversight Board (PCAOB) is een organisatie ontstaan, volledig 'los' van het accountantsberoep, met als missie om beleggers in de Verenigde Staten te beschermen door ervoor te zorgen dat jaar- 
rekeningen worden gecontroleerd naar de hoogste standaarden op het gebied van kwaliteit, onafhankelijkheid en ethiek. De PCAOB is, samen met de Securities and Exchange Commission (SEC), verantwoordelijk voor het opstellen van de controlestandaarden, voor kwaliteitsinspecties, voor het bijhouden van een register van tot controle bevoegde kantoren, en ten dele voor handhaving. Het definitieve einde derhalve van zelfregulering, in elk geval ten aanzien van de beursgenoteerde ondernemingen.

En hoe zit het in Europa? Is ook hier het einde van zelfregulering in zicht? Wie dezer maanden de ontwikkelingen rondom de 8ste EG-richtlijn en de Wet Toezicht Accountantsorganisaties volgt, kan wellicht tot die conclusie komen. Een onafhankelijke toezichthouder, met verantwoordelijkheden op het gebied van registratie, kwaliteitsmonitoring en handhaving lijkt aardig op het PCAOB-model. Toch is er een wezenlijk verschil, en dat zit in de 'standards setting'. Want waar de PCAOB er nadrukkelijk voor heeft gekozen om die rol zelfstandig in te vullen, is dat niet de bedoeling binnen de Europese en de Nederlandse context. Europa heeft de intentie uitgesproken om aan te willen sluiten bij de International Standards on Auditing (ISA's), uitgevaardigd door de International Auditing and Assurance Standards Board (IAASB), welke resideert onder de International Federation of Accountants (IFAC). IAASB rekent het dan ook tot haar taak, om een set van standaarden te ontwikkelen voor zowel de controle van jaarrekeningen als voor de uitvoering van andere assurance-services, die appelleert aan het publieke belang.

Is het de moeite waard om dit laatste element van zelfregulering nog te handhaven, waar nagenoeg alle andere componenten inmiddels bij een onafhankelijke toezichthouder zijn ondergebracht? Ik meen van wel. 'Wie het spel niet beoefent moet zich ook niet met de spelregels bemoeien', zo becommentarieerde Wim Kan ooit het standpunt van het Vaticaan over geboortebeperking. Even los van deze specifieke casus, geloof ik inderdaad dat zowel de kwaliteit van de regelgeving als het draagvlak onder professionals erbij gebaat is wanneer de regels worden gemaakt door professionals die dagelijks in de praktijk met hun 'eigen' regels worden geconfronteerd, en aldus de kwaliteit ervan kunnen valideren en de behoefte aan nieuwe regelgeving kunnen signaleren. Voorts is terecht denk ik de vraag aan de orde, of het vanuit de Trias Politicagedachte wel zo verstandig is om de monitoring- en handhavingstaak en de regelgevende bevoegdheid in één hand te leggen. Nog los van het conceptuele bezwaar tegen een dergelijke vermenging, ontstaat ook het risico dat standaarden niet primair worden ge- schreven vanuit het oogpunt van kwaliteit, maar vanuit de behoefte om handhaving zo goed mogelijk te faciliteren, wat vanuit de toezichthouder geredeneerd verklaarbaar is, maar maatschappelijk gezien suboptimaal kan uitpakken.

Maar teneinde deze beperkte vorm van zelfregulering maatschappelijk aanvaardbaar te doen zijn, moet uiteraard wel aan een aantal condities worden voldaan. Om te beginnen moet de kwaliteit van de standards setting boven iedere vorm van kritiek verheven zijn, en moeten de professionals die betrokken zijn bij standards setting laten blijken dat zij primair het publieke belang dienen. Ik denk dat IAASB de afgelopen jaren heeft laten zien dit uitgangspunt in te kunnen vullen. Een belangrijk element hierbij is de continue dialoog vanuit IAASB met public interest groepen, verenigd in de Consultative Advisory Group (CAG), waarin zowel de agenda van IAASB als de diverse ontwerpstandaarden worden besproken. En een ander belangrijk element is de reeds aangehaalde oprichting van de PIOB, die toezicht gaat houden op onder meer IAASB en de Ethics Committee. Een tweede voorwaarde is uiteraard dat de ISA's op grote schaal zullen worden geïmplementeerd. Erkenning door de Europese Commissie en door IOSCO is in dit kader van eminent belang, evenals de samenwerking die IAASB momenteel al heeft met veel nationale standards setters. En ten slotte nadrukkelijke acceptatie door professionals in de praktijk. En daar zit best nog wel een uitdaging. Want zeker in continentaal Europa, opgegroeid met een op de economische leer gegroeide 'substance over form'-benadering, is het voor veel professionals nog even wennen om 'standards' inderdaad te zien als verplichte stof, als iets wat iedere professional tussen zijn oren moet hebben, in plaats van 'een' visie, verpakt in een bij gelegenheid te raadplegen naslagwerk! Kortom, standards setting hoort bij het beroep. Natuurlijk onder toezicht, natuurlijk in een goede dialoog met relevante stakeholders, maar zonder het kind van kwalitatief hoogwaardige standaarden met het tijdelijk vervuilde badwater van de zelfregulering weg te gooien... 